\title{
Implementasi Pendidikan Karakter Disiplin dalam Mendukung Layanan Kualitas Belajar Siswa
}

\author{
Nadia Rohmah ${ }^{1 *}$, Sholeh Hidayat ${ }^{2}$, Lukman Nulhakim ${ }^{3}$ iD \\ 1,2,3 Jurusan Pendidikan Guru Sekolah Dasar, Universitas Sultan Ageng Tirtayasa, Banten, Indonesia \\ *Corresponding author: nadiarohmah23@gmail.com
}

\begin{abstract}
Abstrak
Pendidikan karakter bagi siswa sekolah dasar masih belum maksimal, hal ini ditunjukkan dengan banyaknya siswa yang kurang disiplin dalam melaksanakan pembelajaran serta masih banyaknya siswa yang melakukan pelanggaran pelanggaran moral. Penelitian ini bertujuan untuk mendeskripsikan strategi pendidikan karakter disiplin pada peserta didik dalam pelaksanaan di kelas IV dan hasil dari implementasi pendidikan karakter disiplin pada pesera didik kelas IV SD. Penelitian ini merupakan penelitian deskriptif kualitatif. Populasi dalam penelitian ini adalah seluruh siswa kelas IV SD, dan sampel dalam penelitian ini adalah siswa kelas IV A yang berjumlah 25 orang siswa. Teknik pengumpulan data dilakukan dengan menggunakan teknik non-tes yakni observasi dan wawancara. Data hasil penelitian kemudian dianalisis dengan menggunakan analisis deskriptif kualitatif yaitu dengan cara reduksi data, penyajian data, dan penarikan kesimpulan atau verifikasi. Berdasarkan penelitian yang telah dilakukan melalui wawancara bahwa guru "memahami" terkait strategi pendidikan karakter disiplin pada peserta didik dalam pelaksanaan proses pembelajaran di kelas IV. Hasil dari observasi guru dalam implementasi pendidikan karakter disiplin pada peserta didik dapat disimpulkan bahwa guru "memahami" pendidikan karakter disiplin kepada peserta didik, serta hasil dari observasi peserta didik dapat disimpulkan bahwa peserta didik memiliki dampak "baik" dengan tercapainya tujuan mengimplementasikan pendidikan karakter disiplin dalam mendukung layanan kualitas belajar untuk melaksanakan kegiatan pembelajaran pada penerapan di kelas.
\end{abstract}

Kata kunci: Pendidikan Karakter, Karakter Disiplin, Kualitas Belajar

\section{Abstract}

This study aims to describe the disciplinary character education strategy of students in the fourth grade implementation and the results of the implementation of disciplinary character education for fourth grade students at SDN Bhayangkari, Serang City. The research method used is descriptive qualitative method from Miles and Huberman which is quoted again by Sugiyono, namely by way of data reduction, data presentation, and drawing conclusions or verification. This research was conducted by triangulating data such as interviews and observations. Based on research that has been conducted through interviews that the teacher "understands" the discipline character education strategy for students in implementing the learning process in grade IV. The results of teacher observations in the implementation of disciplinary character education in students can be concluded that the teacher "understands" disciplinary character education to students, and the results of student observations can be concluded that students have a "good" impact by achieving the goal of implementing disciplined character education in support the quality of learning services to carry out learning activities in the classroom application.

Keywords: Character Education, Character Discipline, Quality of Learning

\begin{tabular}{|c|c|}
\hline History: & Publisher: Undiksha Press \\
\hline Received : 8 Desember 2020 & Licensed: This work is licensed under \\
\hline Revised : 17 Januari 2021 & a Creative Commons Attribution 4.0 License \\
\hline Accepted : 15 Februari 2021 & (c) (7) (9) \\
\hline
\end{tabular}

\section{Pendahuluan}

Pendidikan merupakan suatu upaya yang dilakukan untuk mengembangkan kemampuan dan membentuk watak serta peradaban bangsa yang bermartabat dalam rangka mencerdaskan kehidungan bangsa dengan tujuan untuk perkembangan peserta didik agar 
menjadi manusia yang beriman dan bertaqwa kepada tuhan yang maha esa, berahlak mulia, sehat, berilmu, cakap, kreatif, mandiri dan menjadi warga negara yang demokratis serta tanggung jawab (A. P. Sugiarto et al., 2019). Dalam pendidikan terjadi proses belajar mengajar antara guru dan peserta didik. Belajar diartikan sebagai proses interaksi antara individu dengan lingkungannya, dimana melalui interaksi tersebut individu akan dapat memperoleh pengalaman serta pengetahuan yang baru yang mampu menarik perhatian individu sehingga memungkinkan terjadinya interaksi (Pane \& Dasopang, 2017). Kegiatan belajar dilakukan dengan melibatkan aktivitas fisik maupun psikis yang kemudian menghasilkan suatu perubahan tingkah laku pada diri individu dalam bentuk peningkatan kemampuan yang relative konstan dan bukan disebabkan oleh kematangan atau sesuatu yang bersifat sementara (Hanafy, 2014). Melalui kegiatan belajar peserta didik akan mampu meningkatkan kemampuan serta mengembangkan potensi yang ada dalam dirinya serta mengembangkan berbagai karakter positif melalui pembelajaran pendidikan karakater (Pratiwi \& Laksmiwati, 2016).

Pendidikan karakter merupakan suatu sistem pendidikan yang menanamkan nilai-nilai karakter kepada peserta didik yang didalamnya terkandung komponen pengetahuan, kesadaran individu, tekad, serta adanya kemauan dan tindakan untuk melaksanakan nlai-nilai, baik terhadap Tuhan Yang Maha Esa, diri sendiri, sesama manusia, lingkungan, maupun bangsa, sehingga akan tercipta peserta didik yang bekarakterter mulia (Suwartini, 2017). Pendidikan karakter ini merupakan salah satu bentuk layanan kualitas belajar yang disediakan oleh pemerintah untuk meningkatkan kualitas pendidikan di Indonesia. Namun pada kenyataannya nilai karakter yang ada dalam diri peserta didik masih belum maksimal, hal ini dilihat dari banyaknya siswa yang senang menunda-nunda pekerjaan, datang ke sekolah tidak tepat waktu, tidak memakai seragam yang lengkap sesuai dengan yang tercantum dalam tata tertib sekolah, duduk atau berjalan dengan seenaknya menginjak tanaman (Suriadi et al., 2021; Wuryandani et al., 2014). Selain itu terdapat berbagai macam penyimpangan moral yang dilakukan oleh siswa seperti bullying, seks bebas, narkoba, balapan liar, tawuran, dll (Lestari, 2016).

Salah satu upaya yang dapat dilakukan untuk mengatasi permasalahan tersebut yakni dengan peningkatan layanan kualitas belajar dalam bentuk penanaman pendidikan karakter disiplin. Pendidikan karakter disiplin diyakini mampu mendukung layanan kualitas belajar yang disediakan oleh pemerintah, hal ini dikarenakan dalam pendidikan karakter disiplin peserta didik diajarkan tentang nilai normative yang berlaku di masyarakat (Faradiba \& Royanto, 2018). Pendidikan karakter disiplin bertujuan untuk menghidarkan peserta didik dari prilaku-prilaku yang tidak sesuai dengan norma-norma yang berlaku di masyarakat serta menghidarkan peserta didik dari dampak negatif kemajuan teknologi (Supiana et al., 2019).

Penelitian yang dilakukan oleh Hartati (2017) mengemukakan bahwa pendidikan karakter disiplin siswa dapat dilakukan dengan menerapkan disiplin dalam segala kegiatan di sekolah, membudayakan $5 \mathrm{~s}$, membantu peserta didik untuk mengenali potensi yang ada dalam dirinya, membiasakan siswa untuk gemar membaca, dll. Pernyataan ini juga didukung oleh penelitian yang dilakukan oleh Dewi et al., (2019) yang juga menyatakan bahwa pendidikan karakter disiplin dapat dilakukan dengan melaksanakan kegiatan rutin seperti piket kelas, kegiatan spontan, dan memberikan contoh keteladanan kepada peserta didik seperti dating tepat waktu untuk mengajar siswa di kelas. Penelitian selanjutnya yakni penelitian yang dilakukan oleh Yusuf et al., (2020) yang juga mengemukakan bahwa implementasi pendidikan karakter disiplin di sekolah dilakukan melalui kegiatan rutin di sekolah, ekstrakurikuler dan kerjasama antara orang tua dan pihak sekolah. Berdasarkan ketiga hasil penelitian tersebut dapat disimpulkan bahwa terdapat berbagai macam cara yang dapat dilakukan untuk mengimplementasikan karakter disiplin di sekolah. 
Namun pada beberapa penelitian sebelumnya belum terdapat kajian kusus mengenai implementasi pendidikan karakter disiplin pada siswa sekolah dasar, kususnya pada jenjang kelas IV untuk mendukung layanan kualitas belajar, sehingga dalam penelitian ini diupayakan untuk melaksankan penelitian mengenai Implementasi pendidikan karakter disiplin dalam mendukung layanan kualitas belajar Siswa kelas IV SD dengan tujuan untuk mengetahui apa saja upaya serta strategi yang dilakukan oleh pendidik dalam pendidikan karakter disiplin pada peserta didik kelas IV SD serta hasil dari implementasi pendidikan karakter disiplin pada pesera didik kelas IV SDN Bhayangkari Kota Serang.

\section{Metode}

Penelitian ini dilakukan di SDN Bhayangkari tahun ajaran 2020/2021. Penelitian ini menggunakan metode deskriptif kualitatif yang berfungsi untuk menjelaskan terjadinya suatu kejadian. Populasi dalam penelitian ini yakni seluruh siswa kelas IV di SDN Bhayangkari. Penarikan sampel dilakukan dengan menggunakan teknik random sampling dan didapatkan kelas sampel yakni kelas IV A dengan jumlah siswa sebanyak 25 orang. Pengumpulan data dalam penelitian ini dilakukan dengan menggunakan metode non-tes yakni observasi dan wawancara. Dengan menggunakan instrument berupa pedoman wawancara. Analisis data dilakukan dengan menggunakan analisis lapangan dari Miles and Huberman, yang telah dikutip oleh Sugiyono, (2015) dengan tiga cara yaitu reduksi data, penyajian data, dan penarikan kesimpulan.

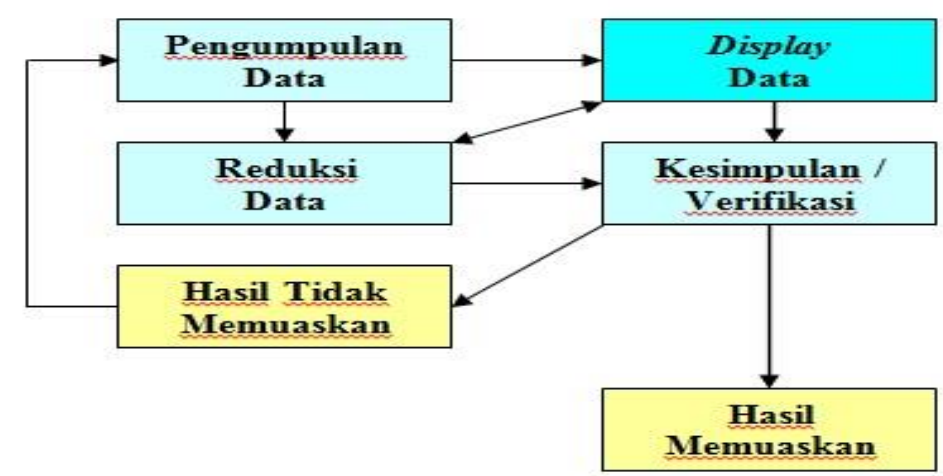

Gambar 1. Analisis Data dari Miles and Huberman

Tabel 1. Pedoman Instrumen Wawancara dan Observasi Guru

\begin{tabular}{cl}
$\begin{array}{c}\text { Ruang Lingkup } \\
\text { Penelitian }\end{array}$ & \multicolumn{1}{c}{ Indikator Penelitian } \\
\hline & $\begin{array}{l}\text { Strategi dalam memberikan contoh dan keteladanan } \\
\text { Strategi dalam membiasakan kedisiplinan }\end{array}$ \\
Dampak penguatan & $\begin{array}{l}\text { Strategi dalam menegakkan peraturan kedisiplinan } \\
\text { karakter disiplin }\end{array}$ \\
& $\begin{array}{l}\text { Strategi dalam memberikan hukuman terhadap pelanggaran } \\
\text { kedisiplinan }\end{array}$ \\
\hline
\end{tabular}

Tabel 2. Pedoman Instrumen Observasi Siswa

\begin{tabular}{cl}
\hline Ruang Lingkup Penelitian & \multicolumn{1}{c}{ Indikator Penelitian } \\
\hline \multirow{2}{*}{ Dampak penguatan karakter } & Kedisiplinan dalam aspek belajar \\
disiplin & Kedisiplinan dalam aspek mentaati peraturan \\
& Kedisiplinan dalam aspek waktu \\
& Kedisiplinan dalam aspek berpakaian \\
\hline
\end{tabular}




\section{Hasil dan Pembahasan}

Penelitian ini dilakukan untuk mendeskripsikan strategi pelaksanaan pendidikan karakter disiplin pada siswa dan juga untuk menggambarkan hasil dari implementasi pendidikan karakter disiplin bertujuan untuk perubahan karakter yang terjadi pada siswa di SDN Bhayangkari Kota Serang.

\section{Implementasi Pendidikan Karakter Disiplin dalam Mendukung Layanan Kualitas Belajar Siswa \\ Strategi dalam Memberikan Contoh dan Keteladanan}

Informasi mengenai strategi yang dilakukan oleh guru mengenai strategi dan contoh keteladanan didapatkan melalui proses wawancara bersama bapak Achmad Rifqi yang telah mengajarnya kurang lebih 13 tahun di SDN Bhayangkari semenjak tahun 2007. Berdasarkan hasil wawancara didapatkan informasi bahwa penguatan pendidikan karakter di SDN Bhayangkari sudah mulai menerapkannya pada penerapan kurikulum 2013. Menurut bapak Achmad Rifqi, sebagai pendidik tidak cukup hanya memberikan prinsip saja untuk mendidik siswa yang pintar, karena yang lebih penting bagi siswa adalah figur atau sebagai contoh baik yang memberikan keteladanan terhadap siswa, kemudian keteladanan dalam pendidikan merupakan metode yang berpengaruh dan terbukti yang paling berhasil dalam mempersiapkan serta mengembangkan aspek moral, spiritual, dan etos sosial siswa. Bahkan bentuk perkataan, perbuatan dan tindak tanduknya, akan senantiasa tertanam dalam kepribadian siswa di kelas IV. Keteladanan berkaitan dengan segala sesuatu yang terkait dengan perkataan, perbuatan, sikap, dan perilaku seseorang yang dapat ditiru atau diteladani oleh siswa (Pohan, 2020; Wardhani \& Wahono, 2017). Sehingga seorang guru dituntut untuk memiliki perilaku yang baik, pengetahuan dan tingkat religius yang tinggi sehingga dapat memberikan contoh yang baik kepada siswanya (Yuhana \& Aminy, 2019).

\section{Strategi dalam Membiasakan Kedisiplinan}

Pembiasaan kedisiplinan untuk siswa sangat penting menurut bapak Achmad Rifqi, pembiasaan dalam kedisiplinan untuk siswa dilakukan agar setiap kegiatan di sekolah dapat teratur dalam pelaksanaannya. Melalui pembiasaan kedisiplinan siswa akan terbiasa untuk melakukan sesuatu hal dengan baik, dalam kegiatan belajar maupun kegiatan lainnya di lingkungan sekitar sekolah dan juga meminalisasi adanya kegiatan siswa yang kurang baik contohnya menggangu temannya yang sedang bermain yang nantinya akan terjadi keributan (Hidayati et al., 2020). Pembiasaan kedisiplinan merupakan point utama dasar untuk kebaikan siswa dalam pola belajar ataupun masuk dengan nilai sosial terhadap temantemannya (Syah, 2019). Di SDN Bhayangkari penerapan kedisiplinan dilakukan dengan memberikan contoh datang tepat waktu di sekolah guna mengantisipasi ketinggalan dalam materi belajar ketika sudah mulai pembelajaran berlangsung. Selain itu juga sebelum memasuki kelas, siswa diminta guru untuk di cek terlebih dahulu kerapihannya oleh ketua kelas seperti cek kuku, perlengkapan seragam dan juga kerapihan rambut. Sebelum pembelajaran di mulai para siswa di arahkan untuk melihat kolong mejanya masing-masing jika ada sampah untuk di punguti dan di buang ke tempat sampah supaya ketika pembelajaran sudah dimulai lingkungan kelas terlihat bersih dan siswa pun dapat fokus dalam belajar.

Contoh-contoh sederhana seperti diatas memberikan pengaruh yang besar bagis siwa, beliau bisa merasakan perubahan dalam setiap perilaku siswa untuk melihat kegiatan kebiasaannya di sekolah. Tentunya dengan proses memberikan disiplin siswa tidak cepat menanggapinya, oleh karena itu sebagai pendidik harus sabar dalam menghadapi siswa dengan karakter yang berbeda. Dengan berjalannya waktu akan ada perubahan tersendiri untuk siswa melakukan apa yang sudah guru berikan. Hal ini sejalan dengan penelitian yang 
dilakukan oleh Dewi et al., (2019) yang juga menyatakan bahwa pembiasaan kegiatan sederhana sehari-hari seperti melaksanakan piket kelas, datan tepat waktu, dan kegiatan pembiasaan lainnya secara tidak langsung akan menanamkan nilai-nilai disiplin dalam diri anakh sehingga akan dapat meningkatkan kualitas layanan belajar.

\section{Strategi dalam Menegakkan Peraturan Kedisiplinan}

Strategi yang dilakukan dalam menegakkan peraturan kedisiplinan belajar yakni dengan memberikan hukuman atau punishment kepada siswa yang melakukan pelanggaran kedisiplinan (Najmuddin et al., 2019; Nurjannah et al., 2020). Pemberian hukuman kepada siswa dilakukan agar dapat memberikan efek jera, serta kepada siswa yang melanggar (Rahmawati \& Hasanah, 2021). Hukuman yang diberikan merupakan hukuman yang sesuai dengan usia serta pelanggaran yang dilakukan oleh siswa seperti jika siswa tidak membuat tugas maka akan dihukum dengan cara membersihkan kelas ataupun ditambahkan tugas supaya menambah giat dalam mengerjakan tugas dan tanggung jawab dalam menyelesaikan tugasnya (Yusdiani \& Sulaiman, 2018).

Dalam pelaksanaannya tidak semua peraturan yang di berikan guru akan diikuti siswa dikarenakan setiap siswa mempunyai karakter yang berbeda-beda, maka dari itu membutuhkan waktu dan proses dalam memberikan peraturan yang kita sudah terapkan secara perlahan supaya siswa akan mengikutinya. Menurut bapak Achmad Rifqi manfaat yang dapat dirasakan saat memberikan penegakan peraturan kedisiplinan bagi siswa yakni siswa lebih menghargai waktu yang berharga dengan datang tepat waktu ke sekolah. Adapun kendala yang dirasakan selama melaksanakan penegakan kedisiplinan yakni terdapat beberapa siswa yang tidak peduli terhadap teguran yang diberikan oleh guru serta tetap melakukan pelanggran meskipun telah diberikan hukuman. Sehingga pelaksanaan penegakan aturan kedisiplinan harus benar-benar memiliki manfaat secara logis dalam rangka membangun suasana kelas yang kondusif untuk pembelajaran (Rohman, 2018).

\section{Strategi dalam Memberikan Hukuman terhadap Pelanggaran Kedisiplinan}

Pelanggaran disiplin yang terjadi di suatu sekolah disebabkan karena masih rendahnya kesadaran siswa akan kedisiplinan (Nurjannah et al., 2020). Jika membicarakan tentang disiplin sekolah tidak bisa dilepaskan dengan persoalan perilaku negatif siswa. Perilaku negatif yang terjadi di kalangan siswa remaja pada akhir-akhir ini tampaknya sudah sangat mengkhawarirkan. Di lingkungan internal sekolah pun pelanggaran terhadap berbagai aturan dan tata tertib sekolah masih sering ditemukan yang menentang dari pelanggaran tingkat ringan sampai dengan pelanggaran tingkat tinggi, seperti kasus bolos, perkelahian, nyontek, pemalakan, pencurian dan bentuk-bentuk penyimpangan perilaku lainnya (Wuryandani et al., 2014). Tentu saja, semua itu membutuhkan upaya pencegahan dan penanggulangan, dan di sinilah arti penting disiplin sekolah.

Sekolah merupakan salah satu faktor dominan dalam membentuk dan mempengaruhi perilaku siswa (Yuliantika, 2017). Di sekolah seorang siswa berinteraksi dengan para guru yang mendidik dan melakukan sikap, teladan, perbuatan dan perkataan para guru yang dilihat dan didengar serta dianggap baik oleh siswa dapat meresap masuk ke dalam hati sanubarinya dan dampaknya kadang-kadang melebihi pengaruh dari orang tuanya di rumah (W. Sugiarto, 2019). Sikap dan perilaku yang ditampilkan guru tersebut pada dasarnya merupakan bagian dari upaya pendisiplinan siswa di sekolah. Upaya pendisiplinan dapat dilakukan dengan memberikan aturan baku terhadap pola tingkah laku siswa di sekolah serta pemberian hukuman kepada siswa. Pemberian hukuman sebaiknya perlu memperhatikan frekuensi, durasi dan intensitas pemberian hukuman (Ela et al., 2017). Hukuman bukan berorientasi pada karakter dan sifat anak yang cenderung tidak tampak melainkan lebih pada perilaku 
tampak yang bisa diubah, dikurangi dan atau ditingkatkan (Eliza \& Neviyarni, 2020). Namun pada dasarnya hukuman itu harus selaras dengan kesalahan.

Selanjutnya hukuman itu harus adil berdasarkan atas rasa objektif, tidak memihak salah satu dan membuang perasaan subjektif. Misalnya siswa yang lain membersihkan ruangan kelas sementara ada siswa yang hanya duduk-duduk sambil bernyanyi-nyanyi tak ikut bekerja. Maka hukumannya ikut bekerja sesuai dengan teman-temannya dengan waktu ditambah sama dengan keterlambatannya tanpa memandang siswa mana yang melakukannya. Dan yang terakhir hukuman itu harus lekas dijatuhkan. Hal ini bertujuan agar siswa segera paham hubungan dari kesalahannya. Pendidik pun harus jelas menunjukkan pelanggaran yang diperbuat siswa. Dengan harapan siswa segera tahu dan sadar mempersiapkan perbaikannya. Pendidik tidak diperkenankan asal memberi hukuman sehingga siswa bingung menanggapinya.

\section{Hasil Implementasi Pendidikan Karakter Disiplin dalam Kualitas Belajar Siswa Kedisiplinan dalam Aspek Belajar}

Menurut A.R, perlu menanamkan kedisiplinan dalam setiap pembelajaran di kelas karena sikap kedisiplinan belajar untuk siswa sangatlah penting agar mereka bisa selalu menghargai gurunya yang sedang menerangkan materi pelajaran dengan tidak mengobrol atau diam dan hanya memerhatikan, setelah itu sikap kedisiplinan pun penting untuk dirinya sendiri yaitu dengan adanya siswa mempunyai sopan santun terhadap orang lain salah satunya kepada orang tuanya sendiri. Jadi sebagai seorang guru memiliki berbagai tanggung jawab dan tugas yang harus dilaksanakan sesuai dengan tuntutan profesi guru. Hal ini sejalan dengan pernyataan Umasugi (2020) yang menyatakan bahwa tugas utama dan terpenting yang menjadi tanggung jawab seorang guru adalah memajukan, merangsang dan membimbing siswa dalam proses belajar. Segala usaha kearah itu harus dirancang dan dilaksanakan. Guru yang berkesan dalam menjalankan tugasnya adalah guru yang berhasil menjadikan siswanya termotivasi dalam pelajaran (Oktiani, 2017). Oleh karena itu agar lebih berkesan dalam pengajaran, guru harus berusaha memahami makna motivasi belajar itu sendiri dan mengembangkan serta menggerakkan motivasi pembelajaran siswa ke arah yang lebih baik.

Selain itu sederhana saja beliau mengajarkan sikap kedisiplinan belajar siswa dengan cara selalu mengucap salam ketika masuk kelas dan salam sama guru kelas, lalu selalu mengikuti pembelajaran dengan baik dalam artian tidak berbuat tindakan yang mengacaukan kelas sehingga menggangu pembelajaran sedang berlangsung. Namun, selain sikap kedisiplinan ke guru lalu sesama teman sebayanyapun sangatlah penting karena mereka bisa mempunyai teman dengan sikap sederhana yaitu sikap disiplin tidak selalu egois ataupun meledek temannya yang lagi bermasalah terhadap guru ataupun teman sebayanya, namun alangkah baiknya sikap guru ataupun temannya merangkul teman yang sedang bermasalah supaya bisa lebih tenang dan nyaman dengan suasanananya. Setelah kita sudah memberikan contoh hal sederhana terkait sikap disiplin kepada siswa menurut beliau, adapun beberapa cara dalam menerapkan sikap disiplin dalam kegiatan proses pembelajaran yang mana disiplin bisa menghargai dengan tanggapan temannya persoalan tugas dalam sebuah diskusi yang sudah diatur oleh guru, siswa pun bisa menghargai keputusan guru dalam pembelajaran yang sudah diberikan dengan cara guru membuat instrumen pengamatan sikap yang didalamnya memuat poin-poin penilaian dengan skala tertentu beserta dengan rubrik penilaiannya. Poin-poin penilaian tersebut misalnya dapat berupa pernyataan sebagai berikut siswa mampu menghargai pendapat orang lain, siswa tidak memotong pembicaraan orang lain selama proses diskusi, siswa tidak memaksakan pendapatnya kepada orang lain, siswa mampu menerima dengan lapang dada apabila dirinya salah, siswa mampu mengutarakan 
pendapat dengan sopan, siswa tidak menyinggung perasaan orang baik dalam perkataan maupun perbuatan, dan lain sebagainya.

Adapun teknis penilaiannya yaitu guru mengamati sikap siswa selama proses diskusi satu persatu dan memberikan penilaian pada instrumen yang telah disiapkan. Jadi metode penilaian "saling menilai" di atas diharapkan mampu memicu siswa untuk lebih bertoleransi dengan siapapun. Siswa akan lebih berhati-hati dalam bersikap agar tidak sampai mendapat penilaian yang jelek baik dari guru maupun temannya sendiri. Siswa akan merasa terus diamati sehingga siswa akan berbuat yang terbaik dimanapun dan kapanpun dia berada. Respon disiplin belajar itu sendiri cukup baik terbukti dari hampir tidak pernah atau malah beliau tidak pernah sama sekali melihat saat belajar ada yang berkelahi di kelas meskipun seringkali beliau melihat ada beberapa perbedaan pendapat antar siswa. Menurut beliau siswa cukup memahami tentang pentingnya sikap disiplin karena hal tersebut merupakan etika dasar yang pastinya sudah diajarkan dirumahnya masing-masing, namun meskipun begitu sekolah terutama guru wajib untuk mengajarkan kembali hal tersebut kepada siswa.

Pengaruhnya untuk siswa dalam sikap disiplin sangat terlihat. dengan cara seperti itu siswa mampu mempunyai karakter yang baik yaitu dengan adanya sopan santun terhadap siapapun mampu bertanggung jawab apa yang mereka sudah lakukan dalam artian ada salah satu siswa yang kehilangan pulpennya lalu teman sebangkunya membantu mencarikan pulpennya karena itu dia melakukan sikap menghargai terhadap temannya supaya temannya tidak ketinggalan dalam hal belajar, bukan sebaliknya diacuhkan atau tidak dipedulikan oleh teman sebangkunya namun lebih baiknya dibantu ataupun ikut serta mencarikannya. Adapun terkait hal lain yaitu dengan cara berbagi untuk teman sebayanya yang tidak makan karena tidak ada uang untuk membelinya jadi fungsi sebagai temannya yaitu menawarkan makanan untuk temannya yang sedang kesusahan karena menghargai temannya yang sedang lapar ataupun hanya berdiam diri.

\section{Kedisiplinan dalam Aspek Menaati Peraturan}

Dalam menaati peraturan di sekolah, beliau selalu menerapkan peraturan sekolah kepada siswa seperti datang tepat pada waktunya ke sekolah jam 07.00 sudah ada di sekolah, namun ada hal lain yang beliau jelaskan tentang kedisiplinan dan menaati peraturan sekolah sangatlah penting. kedisiplinan merupakan cerminan diri kita yang sesungguhnya. Dengan disiplin kita bisa mengetahui bahwa siapa sesungguhnya diri kita itu. Disiplin dan menaati peraturan merupakan pedoman bagi sekolah untuk menciptakan suasana sekolah yang aman dan tertib sehingga akan terhindar dari kejadian-kejadian yang bersifat negative (Dewita \& Indrawadi, 2020). Hukuman yang diberikan ternyata tidaklah ampuh untuk menangkal beberapa bentuk pelanggaran, malahan akan mempertambah permasalahan. Beberapa kejadian yang bersifat negatif harus segera ditanggulangi dan ditangkal.

Selain itu peraturan itu wajib siswa ikuti karena itu bisa menjadikan kebiasaan yang baik untuk siswa agar menjadi lebih disiplin, dalam ketertiban yang beliau sudah berikan terkait menaati peraturan waktu dan menjaga kebersihan adapun menaati peraturan dalam belajar di dalam kelas sebelum dimulai dengan melakukan selalu mengarahkan siswa khususnya kelas IV di SDN Bhayangkari untuk selalu membaca buku sebelum kegiatan belajar mengajar dimulai dalam kelas, supaya siswa lebih tahu materi yang akan diajarkan oleh guru nanti. Manfaatnya untuk kemandirian dan pengetahuan siswa lebih mengetahui dengan sendirinya dan adapun pertanyaan nanti yang diajukan oleh siswa karena disitulah siswa mulai merasa belajar dan dapat ilmunya selain dari guru dari diri sendirinya pun mengetahui apa yang ingin dilakukan ataupun ditanyakan kepada guru setelah kegiatan belajar mengajar dimulai. Adapun layanan konseling khusus guru wali kelasnya kelompok pelanggaran terhadap menaati peraturan sekolah dapat dihindari bahkan dihilangkan ataupun diajarkan menjadi yang lebih baik lagi untuk siswa khususnya kelas IV di SDN Bhayangkari. 


\section{Kedisiplinan dalam Aspek Waktu}

Menurut A.R, beliau selalu menerapkan disiplin waktu di sekolah kepada siswa seperti halnya datang tepat pada waktunya ke sekolah. Namun ada hal lain yang beliau jelaskan tentang kedisiplinan dan menaati peraturan sekolah sangatlah penting. Kedisiplinan waktu merupakan cerminan diri kita yang sesungguhnya. Lalu peraturan itu wajib siswa ikuti karena itu bisa menjadikan kebiasaan yang baik untuk siswa untuk menjadi lebih disiplin. Dalam ketertiban yang beliau sudah berikan terkait menaati peraturan waktu dan menjaga kebersihan adapun menaati peraturan dalam belajar didalam kelas sebelum dimulai dengan melakukan selalu mengarahkan siswa khususnya kelas IV di SDN Bhayangkari untuk selalu membaca buku sebelum kegiatan pembelajaran di mulai dalam kelas, supaya siswa lebih tahu materi yang akan di ajarkan oleh guru nanti.

Dalam pelaksanaan manajemen kelas dan memaksimalkan waktu belajar, guru dapat membuat kesepakatan bersama dengan para siswa tentang konsekuensi dari berbagai macam perilaku keterlambatan dalam mengajarkan atau mengumpulkan tugas. Aturan ini dapat menumbuhkan di dalam diri mereka nilai tanggung jawab dan ketekunan. Sekolah juga bisa menerapkan penbelajaran tematis, yaitu mengalokasikan waktu khusus untuk mengajarkan nilai tertentu sebagai prioritas pembentukan karakter. Lembaga pendidikan mendesain sendiri tema dam prioritas nilai pendidikan karakter yang ditekankan. Penguatan ini dikerjakan melalui mata pelajaran serta alokasi dan guru khusus untuk memaparkan materi pelajaran yang memperkuat pendidikan karakter. Pendidikan karakter berbasis budaya sekolah termasuk di dalam yang keseluruhan tata kelola sekolah, desain kurikulum tingkat satuan pendidikan, pembuatan tata peraturan, dan norma sekolah.

\section{Simpulan}

Berdasarkan penelitian yang telah dilaksanakan Strategi pelaksanaan pendidikan karakter disiplin pada siswa dapat disimpulkan bahwa beliau memahami dengan mengetahui cara mengembangkan kreativitas siswa, mengetahui cara berkomunikasi dengan baik terhadap semua pihak sekolah serta mengetahui cara melakukan strategi keteladanan kedisiplinan dan juga penegakan peraturan dalam disiplin terhadap siswa. Hasil dari implementasi pendidikan karakter disiplin pada siswa dapat disimpulkan bahwa guru kelas IV.A terimplementasi baik dalam menerapkan karakter disiplin pada siswa, karena peneliti lihat di lapangan dengan cara kedisiplinan dalam aspek belajar, menaati peraturan serta kedisiplinan dalam aspek waktu yang sudah ditentukan oleh guru terhadap siswa.

\section{Daftar Rujukan}

Dewi, A. K. T., Degeng, I. N. S., \& Hadi, S. (2019). Implementasi Pendidikan Nilai Karakter di Sekolah Dasar Melalui Budaya Sekolah. Jurnal Pendidikan: Teori, Penelitian Dan Pengembangan, 4(2), 247-255. https://doi.org/http://dx.doi.org/10. 17977/jptpp.v4i2.12011.

Dewita, E., \& Indrawadi, J. (2020). Interaksi Guru Dan Siswa Dalam Pembinaan Disiplin Siswa Pada Pembelajaran Pendidikan Pancasila Dan Kewarganegaraan. Jurnal Pendidikan Ilmu Sosial, 12(1). https://doi.org/10.24114/ jupiis.v12i1.16411.g13235.

Ela, Nurhaidah, \& Intan. (2017). Pemberian Punishment Yang Dilaksanakan Guru Di SD Negeri 4 Banda Aceh. Jurnal Ilmiah Pendidikan Guru Sekolah Dasar, 2(d), 12-21. http://www.ejournal.kampusmelayu .ac.id/index.php/akademika/article/view/85/77.

Eliza, R., \& Neviyarni. (2020). Perilaku Siswa yang Tidak Dikehendaki (Off Task Behavior) dan Penanganan Konselor. Jurnal Bimbingan Dan Konseling, 1(2). https://doi.org/0.32505/syifaulqulub.v1i2.2465.

Faradiba, A. T., \& Royanto, L. R. M. (2018). Karakter Disiplin, Penghargaan, dan Tanggung 
Jawab dalam Kegiatan Ekstrakurikuler. Jurnal Sains Psikologi, 7(1), 93-98. https://doi.org/ 10.17977/um 023v7i12018p93.

Hanafy, M. S. (2014). Konsep Belajar Dan Pembelajaran. Lentera Pendidikan: Jurnal Ilmu Tarbiyah Dan Keguruan, 17(1), 66-79. https://doi.org/10.24252/lp.2014v 17n1a5.

Hartati, W. (2017). Implementasi Pendidikan Karakter Disiplin Di SD Negeri 7 Tanjung Raja. JMKSP (Jurnal Manajemen, Kepemimpinan, Dan Supervisi Pendidikan), 2(2). https://doi.org/10.31851/jmksp.v2i2.1470.

Hidayati, N., Hakim, N., \& Sulton, M. Z. (2020). Pendidikan Karakter Melalui Pembiasaan Rutin Untuk Menanamkan Nilai - Nilai Pendidikan Islam Pada Siswa SD/MI. Jurnal of Islamic Elementary Education, 2(2). https://doi.org/10.51675/ jp.v2i2.104.

Lestari, P. (2016). Membangun Karakter Siswa Melalui Kegiatan Intrakurikuler, Ekstrakurikuler, dan Hidden Curriculum di SD Budi Mulia Dua Pandeansari Yogyakarta. Jurnal Penelitian, 10(1), 71. https://doi.org/10.21043/jupe.v10i1.1367.

Najmuddin, N., Fauzi, F., \& Ikhwani, K. (2019). Program Kedisiplinan Siswa Di Lingkungan Sekolah: Studi Kasus di Dayah Terpadu (Boarding School) SMA Babul Maghfirah Aceh Besar. Jurnal Pendidikan Islam, 8(2). https://doi.org/ 10.30868/ei.v8i2.430.

Nurjannah, E., Masudi, M., Baryanto, B., Deriwanto, D., \& Karolina, A. (2020). Strategi Guru Mata Pelajaran Akidah Akhlak dalam Meningkatkan Kedisiplinan Belajar Siswa. Journal of Education and Instruction, 3(2). https://doi.org/ 10.31539/joeai.v3i2.1381.

Oktiani, I. (2017). Kreativitas Guru dalam Meningkatkan Motivasi Belajar Peserta Didik. JUrnal Kependidikan, 5(2). https://doi.org/https://doi.org/10.24090/jk.v5i2.1939.

Pane, A., \& Dasopang, M. D. (2017). Belajar Dan Pembelajaran. Fitrah:Jurnal Kajian IlmuIlmu Keislaman, 3(2), 333. https://doi.org/10.24952/fitrah.v3i2.945.

Pohan, I. S. (2020). Penerapan Nilai-Nilai Keteladanan Oleh Guru Serta Implikasinya Bagi Perilaku Siswa Di Sekolah Dasar Negeri 054874 Desa Selayang Kecamatan. Jurnal Penelitian Dan Pengabdian Masyarakat UISU, 9(2). https://jurnal. uisu.ac.id/index.php/wahana/article/view/3561/2448.

Pratiwi, I. D., \& Laksmiwati, H. (2016). Kepercayaan Diri dan Kemandirian Belajar Pada Siswa SMA Negeri "X." Jurnal Psikologi Teori Dan Terapan, 7(1), 43. https://doi.org/10.26740/jptt.v7n1.p43-49.

Rahmawati, E., \& Hasanah, U. I. (2021). Pemberian Sanksi (Hukuman) Terhadap Siswa Terlambat Masuk Sekolah Sebagai Upaya Pembentukan Karakter Disiplin. Indonesian Jurnal of Teacher Education, 2(1). https://journal.publication-center.com /index.php/ijte/article/view/262.

Rohman, F. (2018). Peran Pendidik Dalam Pembinaan Disiplin Siswa Di Sekolah / Madrasah. Jurnal Pendidikan Bahasa Dan Sastra IArab, 4(1), 72-94. http://jurnal. uinsu.ac.id/index.php/ihya/article/view/1467/1196.

Sugiarto, A. P., Suyati, T., \& Yulianti, P. D. (2019). Faktor Kedisiplinan Belajar pada Siswa Kelas X SMK Larenda Brebes. Jurnal Mimbar Ilmu, 24(2), 232-238. https://doi.org/http://dx.doi.org/10.23887/mi.v24i2.21279.

Sugiarto, W. (2019). Pendidikan Nilai Dan Masa Depan Bangsa. Jurnal Akademika, 15(2), $43-51$.

http://www.ejournal.kampus melayu.ac.id/index.php/akademika/article/view/85/77.

Sugiyono. (2015). Metode Penelitian dan Pengembangan (Research and Development/ $R \& D)$. Alfabeta.

Supiana, Hermawan, H., \& Wahyuni, A. (2019). Manajemen Peningkatan Karakter Disiplin Peserta Didik Melalui Kegiatan Ekstrakurikuler. Jurnal Islamic Education Manajemen, 4(2), 193-208. https://doi .org/10.15575/isema.v4i2.5526.

Suriadi, H. J., Firman, F., \& Ahmad, R. (2021). Analisis Problema Pembelajaran Daring 
Terhadap Pendidikan Karakter Peserta Didik. Edukatif: Jurnal Ilmu Pendidikan, 3(1), 165-173. https://doi.org/10. 31004/edukatif.v3i1.251.

Suwartini, S. (2017). Pendidikan Karakter dan Pembangunan Sumber Daya Manusia Keberlanjutan. Jurnal Pendidikan, 4(1), 220-234. https://doi.org/10.30738/trihayu .$v 411.2119$.

Syah, imam jihan. (2019). Metode pembiasaan sebagai upaya dalam penanaman kedisiplinan anak terhadap pelaksanaan ibadah. Journal of Childhood Education, 1(1). https://core.ac.uk/reader/268104460.

Umasugi, H. (2020). Guru Sebagai Motivator. Jurnal Agama Dan Ilmu Pengetahuan, 7(2). http://e-jurnal.staibabussalamsula.ac. id/index.php/JUANGA/article/view/7.

Wardhani, N. W., \& Wahono, M. (2017). Keteladanan Guru Sebagai Penguat Proses Pendidikan Karakter. Untirta Civic Education Journal, 2(1). https://doi.org/ 10.30870/ucej.v2i1.2801.

Wuryandani, W., Maftuh, B., \& Budimansyah, D. (2014). pendidikan karakter disiplin di sekolah dasar. Jurnal Cakrawala Pendidikan, 2, 286-295. https://doi.org/ 10.21831/cp.v2i2.2168.

Yuhana, A. N., \& Aminy, F. A. (2019). Optimalisasi Peran Guru Pendidikan Agama Islam Sebagai Konselor dalam Mengatasi Masalah Belajar Siswa. Jurnal Penelitia Pendidikan, 7(1). https://doi.org/ 10.36667/jppi.v7i1.357.

Yuliantika, S. (2017). Analisis Faktor-Faktor Yang Mempengaruhi Disiplin Belajar Siswa Kelas X, Xi, Dan Xii Di Sma Bhakti Yasa Singaraja Tahun Pelajaran 2016/2017. Jurnal Pendidikan Ekonomi Undiksha, 9(1). https://doi.org/ /10.23887/jjpe.v9i1.19987.

Yusdiani, U. N., \& Sulaiman, Y. S. (2018). Penanaman Budaya Disiplin Terhadap Peserta Didik Kelas VI Mis Guppi Laikang Kecamatan Kajang Kabupaten Bulukumba. Jurnal Inspirasi Pendidikan, 7(2). https://doi.org/10.24252/ip.v7i2.7856.

Yusuf, M., Ritonga, M., \& Mursal, M. (2020). Implementasi Karakter Disiplin dalam Kurikulum 2013 Pada Bidang Studi PAI di SMA Islam Terpadu Darul Hikmah. Jurnal Tarbiyatuna, 11(1), 49-60. https://doi.org/ 10.31603/tarbiyatuna.v11i1.3437. 